\title{
Transforming Universities for a Sustainable Future
}

\author{
Dirk van Damme
}

\section{The Historical Record}

Universities have survived history. They survived numerous revolutions of different natures: scientific, economic, and political. Their millenarian history suggests that their core identity and values stand above time, and the expectation is that they will last many more centuries. Yet, universities, as we know them, face some very serious challenges. In a society where artificial intelligence will fundamentally transform the way we work, connect, participate, and enjoy life, several patterns of research, teaching, and learning which constitute the daily lives of universities will change. Consequently, some have predicted the death of the university as we know it, while others believe that the age of unlimited knowledge will herald the historical triumph of universities.

Universities withstood the test of time because they were flexible enough to adapt to changing circumstances. On top of the medieval and early-modern enlightenment, the scientific revolution of the 17 th century and the industrial revolution of the late 18 th century, the processes of nation-state formation in the 19th and 20th centuries and the massification of educational participation of the late 20th century shaped the modern university. Each subsequent historical stage transformed the modern university, without fundamentally breaking with the accumulated heritage of past phases. Some developments, in particular the massification of educational participation over the past 50 years, forced universities to a real stretch of their educational identity. But, they survived this test gloriously. Thus, they helped modern societies make the transition to an unprecedented level of educational attainment, with over $50 \%$ of the young age cohort (25-34 years-old) qualifying at the tertiary level. On the research front, the expansion of scientific research in the knowledge economy required universities to give up their monopoly and to redefine their value proposition in the

\footnotetext{
D. van Damme $(\bowtie)$

OECD, Paris, France

e-mail: dirk.vandamme@oecd.org

(C) The Author(s) 2021 
research and development chain. Today, universities are widely recognised for their unique role as places for fundamental and applied research and scholarship.

Will universities be able to demonstrate equal degrees of versatility in the $21 \mathrm{st}$ century, marked by disruptions caused by artificial intelligence and many other technological breakthroughs. Will they be capable of adapting to the needs of a lifelong learning society and the changing skill demands of the digital age? Will they be able to endure systemic shocks, such as the COVID19 pandemic? What can we say about the future-readiness of today's universities? How can we foster a sustainable future for the modern university? I will explore some of these questions by discussing two fundamental challenges of the modern university system.

\section{Tackling the Inequalities in the Global University System}

Few modern systems are as global in nature as higher education. From their earliest days, universities aspired to be places of research, scholarship, study, and debate, speaking to the learning community regardless of geographical boundaries. In early modern times, travelling scholars and students were a familiar phenomenon in Europe, but also in other places around the globe, such as the Arab world or China. Today, scientific research is one of the most globally connected and integrated systems of modern human society. Transnational research networks and international co-publishing are growing in scope and impact every year. Talented researchers and academics constitute a global market to which ambitious universities are tapping in order to increase their research output and status. Research is the most powerful driver of internationalisation of universities. However, the education side is following very rapidly. Today, over five million students are mobile and studying in another country worldwide. Still, the numbers are growing every year.

But the internationalisation of universities and academic globalisation are about much more. Despite the absence of any form of global governance, there are important trends and mechanisms of international convergence. International agreements, for example, with regard to recognition of degrees, mutual acceptance of accreditation arrangements, common qualification frameworks, and credit transfer systems, represent important regulatory frameworks for the global system. In certain regions, for example, within the European Union or the European Higher Education Area, they have become very powerful as a result of the Bologna Process. Other regions of the world, often in the context of international trade agreements, have seen similar arrangements put in place. On top of all this, global university rankings are classifying the complex reality of global higher education in an easily readable, but hierarchical and reductionist, list of status and reputation. Thereby falsely suggesting a global level playing field of academic merit. Through these processes of convergence, individual universities have been connected with each other. By this interconnectedness, they have established a truly global system.

Yet, the global higher education system is not without its limits, contradictions, and tensions. There are many signs that the glory days of unbridled internationalisation 
are over. In many countries - the US and the UK are visible examples, but there are many more-nationalist policies seem to take priority over international aspirations. This is not entirely new. Truly global universities constitute only a very small fringe of the system. Most universities define and identify themselves as belonging to specific national systems of history, culture, language, and politics. Universities are making every effort to integrate themselves more firmly in regional knowledge and innovation ecosystems. Political shifts are also important. Conservative opinion leaders in some countries have started to attack universities as 'globalist propaganda machines'. It is very likely that internationalisation and globalisation of higher education are turning into a politically contested reality.

The COVID-19 crisis is accelerating some of the ambiguous trends in global higher education. A first and almost immediate consequence of the pandemic is the sudden fall in the numbers of fee-paying international students. Many foreign students, especially those from Asian countries and China, in particular, left and went back home. For the next academic year, institutions will have to account for a significant income loss from fee-paying international students. For countries where universities have become dependent on this income stream, the situation looks very dire. In the UK, universities estimate the total financial loss of around 6.9-billion-pound sterling, and several university leaders have pressed the government to consider an institutional bail-out. Also, in Australia, another country with universities very much dependent on income from fee-paying international students, similar emergency calls have been heard. Even regardless of the financial consequences, the sudden drop and subsequent reorientation in international student mobility will have a deep impact on the global university landscape.

It is important to look beyond the surface at the more fundamental trends. Global higher education is itself one of the most unequal systems the world has seen. Processes of colonialism, asymmetrical trade, and economic inequalities have deeply influenced the expansion of academic institutions over past centuries. Centres of academic development have been concentrated on the economic and political hegemony of the global order. Since the middle of the 20th century, the global hierarchy of the academic system has been consolidated in these hegemonic countries. Only in recent decades, things have started to change when emerging economies have started to invest and expand their own higher education systems to meet the demand of aspiring and increasingly prosperous middle classes. China, followed by India, is taking the lead as an example to many other emerging economies. It is extremely difficult for ambitious universities in these countries to challenge the power mechanisms behind academic excellence, but China seems to become successful in slowly penetrating the upper ranks of the global system. This will be almost impossible for many other countries. The measurements, definitions, and data collections behind the assessment of academic reputation are not free of cultural bias, and the academic community has a hard time improving its definition of success.

The historical legacy of concentration of academic excellence is increasingly coming at odds with the reality of higher education development and demand. Participation and graduation rates in the countries of academic hegemony are reaching ceiling levels, while demand is exploding in many other parts of the world. From 
around 150 million tertiary graduates worldwide in 2015, we will advance to 300 million in 2030, doubling the numbers. The bulk of that historically unseen expansion of higher education delivery will be in emerging economies such as China, India, Brazil, Indonesia, and Arab states. The share of the United States and Europe in the global pool of graduates will shrink, for the United States from 14\% in 2015 to $8 \%$ in 2030 . Consequently, from a geographical point of view, there will be an enormous mismatch between the location of exploding demand and the location of perceived academic excellence. In itself, this mismatch is driving global student and staff mobility, because people who can afford it look for the best opportunities in the world. Rankings serve as search tools for aspiring students, and in doing so, their biased definition of academic excellence is reinforced.

One of the most important questions facing the global academic community is whether the sharp inequalities in the system are sustainable. In the 21 st century, is it still sustainable to maintain a system that is built on 19 and 20th century premises and is clearly at odds with meeting the needs of demand for knowledge, research, and education in other parts of the world? Is it sustainable to implicitly and explicitly support academic hegemony and power imbalances? And is it even possible to do so when knowledge travels the world at the speed of bits and bytes?

A community, for which freedom of research, the free flow of knowledge, and the power of scientific reason are essential cornerstones of the value system, would enormously benefit from a level playing field between all members, the closing down of historical privilege, and the elimination of power imbalances. This noble idea is getting political traction because of the unique opportunities provided by the United Nations' Sustainable Development Goals (SDGs), including SDG4 on education. These goals, adopted by the international community, are very important drivers for a more sustainable global higher education system. So far, universities have been largely absent in the international debate on SDG4. Recently, things have started to move, and international university associations are making strong arguments in favour of including universities as partners and actors in achieving progress towards the SDGs.

International associations of universities, such as the IAU, can play a very important role in fostering responsible and sustainable internationalisation. They manage the interconnectedness of universities, are the guardians of the shared value system of universities and generate mutual trust in the global system. They should not behave as the safeguards of current hierarchies and power differences in the system but should endeavour to create an inclusive and level playing field for all universities.

\section{Transforming the Universities' Educational Purpose}

Contemporary universities have been educating students for a rather stable professional environment for many decades. The skills needed by professions such as medical doctors, lawyers, psychologists, or even historians and philosophers define the 
framework of programmes. There are well-established scientific disciplines beyond professional fields, such as physics, biology, or political science, which provide the foundations for learning at universities. Academic attitudes and values, such as the search for truthfulness, critical thinking, and dealing with uncertainty permeate all of this.

The identity of the modern university in its teaching and learning function rests on the interplay between research-based professional training, disciplinary education, and academic values. In essence, it is a supply-side approach to education and learning which defines the identity of the university as a learning environment.

However, this approach is coming under pressure in recent years. Universities are increasingly criticised by employers (among other stakeholders) for not listening carefully enough to the skill needs of workplaces in contemporary economies. Critical disputes and tensions between educational institutions and employers on what kind of knowledge and skills graduates bring to the labour market are not new and mostly lead to a productive dialogue. Currently, there are signs indicating that these tensions have accumulated and become explosive, with the risk of short circuits between both sides. An example is the public announcement of the global consultancy firm Ernst \& Young in 2015, stating that it would no longer look at university qualifications when recruiting talent because there was "no evidence that success at university correlates with achievement later in life" (Sherriff 2019).

One of the main reasons for the growing tension between supply-side approaches dominant in universities and calls by employers and other stakeholders to become more demand-sensitive is the profound changes in skill demand, both quantitatively and qualitatively. Universities are doing reasonably well in translating changes in scientific knowledge into course contents but do not identify similarly important changes in skill demand in the external world and transform their education programmes accordingly.

Think, for example, of the consequences of task digitalisation that universityeducated professionals will have to do by 2040. Much more important than which jobs will disappear or how many alternative jobs will emerge as a result of digitalisation, such as robotisation and artificial intelligence, is the question of the changes in the tasks of professionals. Routine tasks, procedural labour and other 'predictable activities', even at a rather high level of cognitive demand, will gradually be taken over by smart machines. Imagine what this will do to legal professions, where large parts of what such professionals do today will be automated. Digitalisation will not only affect low-skilled markets but will have a profound impact on university-educated professionals as well.

The complex and rather unpredictable shifts in skill demand will increase the importance of skills, such as higher-order cognitive skills, complex communication skills, and emotional skills. Higher-order cognitive skills are aligned with the research and analytical skills that universities already develop in many programmes. However, universities see these skills mainly as part of advanced programmes leading to research masters or doctoral degrees. Understanding that such skills should no longer be preserved for students aspiring to research and academic careers, but rather be part of any university education, is a mind shift that most universities still have to 
make. Complex communication skills have slowly become part of the curriculum in various programmes, but a lot is still to be done in this area as well.

Finally, emotional skills are mostly seen as something to be developed in previous stages of a person's educational trajectory. They are also part of the explicit or implicit selection process through which students are admitted to university education. Yet, the evidence clearly shows that emotional skills are part of the 'hidden curriculum' of university education. Universities can transform people into well-rounded individuals also in their personality traits, with clear progress on, for example, conscientiousness and openness. This explains why, even after controlling for variables such as income or employment, university-educated individuals are healthier and have higher levels of interpersonal trust than their lower-educated peers. Addressing changing skill demand will require universities to explicitly look at these 'soft' skills as much as they are looking into higher-level cognitive skills.

In general, universities have been willing to update their curricula and innovate to better meet external demands. In Europe, the implementation of the legislation following the Bologna Process has been an excellent opportunity to critically examine and revise curricula. Universities have prepared to listen more carefully to employerdriven demands and have, for example, included entrepreneurship education in some of their programmes. But, the question is: will this be sufficient? More ambitious and forward-looking answers will be necessary.

In multiple variations on 'the death of the university'-thesis, some experts have argued that universities are something of the past and will no longer be capable of addressing the skill development needs of highly volatile and uncertain economies and societies. These experts believe that radical demand-driven approaches to education and skills will favour a de-institutionalisation of learning and the development of user-driven technology-based learning modes.

Universities will be asked to demonstrate the added value of an institutional and supply-side approach to skills development. This is no easy task. But, the value system of universities, driving inquiry, critical thinking, and scientific attitudes, will prevail in the end. Atomised, user-driven learning, such as we see in many MOOCs or professional training, will never be able to compete with universities for the development of such higher-order skills. That is no reason for complacency, but an argument for more ambitiously developing approaches to teaching and learning that prove to be effective, relevant, and responsible. The really important question thus is what intrinsically defines the educational experience at the university and what makes it so worthwhile. Even if massification has fundamentally modified the dream of the medieval encounter between the master and the pupil or the Humboldtian ideal of research-based Bildung, many students and graduates would still see the personal exchange with researchers and professors and the small-group collaboration with students in laboratories and seminars as the most valuable learning experiences. The COVID-19 crisis and its aftermath might force universities and students to shift their frame of reference of high-quality teaching and learning, but to develop new modes of delivery which are equally motivating and effective, while remaining competitive against alternative modes of provision and certification. This, however, will require an awful lot of imagination, creativity, and ingenuity. Universities need to rethink 
their value for money proposition and examine whether it is not the time to make the necessary investments to make the transition happen.

\section{Conclusion}

In the early decades of the 21 st century, when economies are in deep transformation, the world order is changing, and societies are struck by disruption, universities find themselves in the centre of humanity's hope for sustainable social progress and justice. From climate change to artificial intelligence, pandemics to social cohesion, humanity's hope for survival rests with the knowledge, skills, and wisdom which universities cultivate and transmit. Fulfilling the promise of a sustainable future for humanity requires a successful resolution of some critically important challenges within the university system itself. In this short paper, I briefly discussed two fundamental ones, knowing that there are many more.

Many have predicted the end of the university as we know it today. In contrast, this paper argues that universities will be able to adapt to radically changing circumstances. However, adaptation is not what will characterise universities in the future. We should expect them to also construct the future. That is the meaning of sustainability.

\section{Reference}

Sherriff, L. 2019 (2015) (7 August 2019), Ernst \& Young Removes University Degree Classification From Entry Criteria As There's 'No Evidence' It Equals Success, in HuffPost, Retrieved from: https://www.huffingtonpost.co.uk/2016/01/07/ernst-and-young-removesdegree-classification-entry-criteria_n_7932590.html?guccounter=1 (24.04.2020)

Dirk van Damme is Senior Counsellor in the Directorate for Education and Skills at the OECD in Paris and is also serving as Head of the Centre for Educational Research and Innovation. Between 2017 and 2019 he was also Head of the OECD work on skills. Before joining the OECD, he was professor at Ghent University, General Director of the Flemish Rectors' Conference VLIR (2000-2003) and chief of staff of Flemish education minister Frank Vandenbroucke (2004-2008). He worked extensively with international organisations such as UNESCO, IAUP, EUA, ENQA, INQAAHE and others. 
Open Access This chapter is licensed under the terms of the Creative Commons Attribution 4.0 International License (http://creativecommons.org/licenses/by/4.0/), which permits use, sharing, adaptation, distribution and reproduction in any medium or format, as long as you give appropriate credit to the original author(s) and the source, provide a link to the Creative Commons license and indicate if changes were made.

The images or other third party material in this chapter are included in the chapter's Creative Commons license, unless indicated otherwise in a credit line to the material. If material is not included in the chapter's Creative Commons license and your intended use is not permitted by statutory regulation or exceeds the permitted use, you will need to obtain permission directly from the copyright holder. 